\title{
Crystal Structure of $\mathrm{Ba}_{x} \mathrm{Sr}_{1-\mathrm{x}} \mathrm{TiO}_{3}$ Fine Powder
}

\author{
Natheer B. Mahmood1, Emad K. Al-Shakarchi'1, Brahim Elouadi'2, Xavier Feaugas ${ }^{2}$ \\ ${ }^{1}$ Physics Department, College of Science, Al-Nahrain University, Baghdad, Iraq \\ ${ }^{2}$ Laboratoire des Sciences de l'Ingénieur pour l'Environnement, Université de La Rochelle, La Rochelle, France \\ Email: eks2000@hotmail.com
}

Received 4 January 2015; accepted 24 January 2015; published 28 January 2015

Copyright (C) 2015 by authors and Scientific Research Publishing Inc.

This work is licensed under the Creative Commons Attribution International License (CC BY).

http://creativecommons.org/licenses/by/4.0/

(c) (i) Open Access

\begin{abstract}
Various compositions of the system $\mathrm{Ba}_{x} \mathrm{Sr}_{1-\mathrm{x}} \mathrm{TiO}_{3}$ (BST) have been elaborated both as fine powders and ceramic monoliths, using the co-precipitation route within a warmed supersaturated solution of oxalic acid. The appropriate stoichiometry was determined from the mixtures of precisely titrated aqueous solutions of cations chlorides $\left(\mathrm{SrCl}_{2}, \mathrm{BaCl}_{2}\right.$, and $\left.\mathrm{TiCl}_{4}\right)$. The reason of this process was to apply low sintering temperature in production of BST samples with ultra-fine powders. These powders primarily calcined at $\left(850^{\circ} \mathrm{C}\right)$ for $(5 \mathrm{hr})$ were used to elaborate ceramics after pellets sintering at $\left(1200^{\circ} \mathrm{C}\right)$ during $(8 \mathrm{hrs})$. Indeed, XRD patterns were confirmed that the samples are a pure phase and a perovskite cubic structural type at $(x=0,0.5,0.6)$. Whereas, $(x=0.7,0.8$, $0.9,1)$ showed a tetragonal phase. There is agreement between the FTIR and XRD analysis, by the relation of the wave vector $(\mathrm{K})$ and lattice constant. It was deduced a stimulated relation between $(x)$ and $(K)$. The results of TEM, they were clear that the lowest particle sizes investigated of BST powders nearly $(36-50 \mathrm{~nm})$.
\end{abstract}

\section{Keywords}

Barium Strontium Titanate, Oxalate Co-Precipitation Method, X-Ray Diffraction, Transmission Electron Microscope, Ultra-Fine Powder

\section{Introduction}

Ferroelectric materials with perovskite structure have a wide range of applications, as dielectric, piezoelectric, pyroelectric, electro-optical material. The system $\mathrm{Ba}_{\mathrm{x}} \mathrm{Sr}_{1-\mathrm{x}} \mathrm{TiO}_{3}$ is a ferroelectric material which considered as one of the high dielectric constant material for a number of electronic as well as RF and microwave applications, phase shifter, tunable circuit, varactors, MOSFETs, micro-strip waveguides, Multi-layer ceramic capacitors 
(MLCCs), smart antenna, high gain and high directive antenna and in thermal camera [1]. Barium titanate and strontium titanate are peroviskite structure with the formula $\mathrm{ABO}_{3}$ (Where $\mathrm{A}=\mathrm{Ba}$ or $\mathrm{Sr}, \mathrm{B}=\mathrm{Ti}$ ), $\mathrm{BaTiO}_{3}$ have a ferroelectric curie temperature $\left(\mathrm{T}_{\mathrm{c}}=120^{\circ} \mathrm{C}\right)$ while for $\mathrm{SrTiO}_{3}\left(\mathrm{~T}_{\mathrm{C}}=-250^{\circ} \mathrm{C}\right)$. So, the BST material was solid solution of $\mathrm{BaTiO}_{3}$ and $\mathrm{SrTiO}_{3}$, the substitution factor (x) lead to adjust the ferroelectric Curie temperature in the range $\left(120^{\circ} \mathrm{C}-250^{\circ} \mathrm{C}\right)$ [2] [3]. The conventional method in production $\mathrm{BST}$ was solid state reaction (SSR), by mixing $\mathrm{BaCO}_{3}, \mathrm{SrCO}_{3}$ and $\mathrm{TiO}_{2}$ at high temperature calcinations which is not suitable for high performance application because the material has to undergo some defects such as large particle size, non-homogeneity and presence of impurities.

There are many chemical methods used to get BST powder as a nanoparticle size at low temperature with high-homogeneity rather than SSR, for example sol-gel, co-precipitation, hydrothermal, spray pyrolysis, and modified citrate gel [4]-[9]. The oxalate co-precipitation method was used for the preparation of ultrafine BST powders; it was more efficient in production process by the following parameter, saving energy, short production time, low sintering temperature to avoid grain growth and limited environment impact [10].

\section{Experimental Part}

BST powders were synthesized by Oxalate Co-precipitation method was reported firstly [11] by using Barium chloride $\left(\mathrm{BaCl}_{2} \cdot 2 \mathrm{H}_{2} \mathrm{O}\right)$, Strontium chloride $\left(\mathrm{SrCl}_{2} \cdot 6 \mathrm{H}_{2} \mathrm{O}\right)$, Titanium tetrachloride $\left(\mathrm{TiCl}_{4}\right)$ and Oxalic acid $\left((\mathrm{COOH})_{2} \cdot 2 \mathrm{H}_{2} \mathrm{O}\right)$ as starting materials [8] [9] [12]-[14] as shown in Figure 1. The powders of $\mathrm{Ba}_{\mathrm{x}} \mathrm{Sr}_{1-\mathrm{x}} \mathrm{TiO}_{3}$ with $(\mathrm{x}=1,0.9,0.8,0.7,0.6,0.5,0)$ were prepared by mixing $(50 \mathrm{ml})$ of $1 \mathrm{M}$ of $\mathrm{TiCl}_{4}$, prepared in ice bath, with (50 $\mathrm{ml}$ ) of $1.05 \mathrm{M}$ of $\mathrm{BaCl}_{2}$ and $\mathrm{SrCl}_{2}$ with different value of substitution(x) as shown in the following chemical equation and Table 1. The mixture was added gradually to $(50 \mathrm{ml})$ of $2.2 \mathrm{M}$ of Oxalic acid. The reaction was carried out in water bath at $\left(80^{\circ} \mathrm{C}\right)$ for $(15 \mathrm{~min})$, the resultant powder” Barium Strontium titanyl oxalate tetrahydrate $\left[\mathrm{Ba}_{\mathrm{x}} \mathrm{Sr}_{1-\mathrm{x}} \mathrm{TiO}\left(\mathrm{C}_{2} \mathrm{O}_{4}\right)_{2} \cdot 4 \mathrm{H}_{2} \mathrm{O}\right]$ separated by filtration, washed and dried at $\left(90^{\circ} \mathrm{C}\right)$ for $(12 \mathrm{hr})$. The calcination process was performed at $\left(850^{\circ} \mathrm{C}\right)$ for $(5 \mathrm{hr})$ to get $\mathrm{Ba}_{\mathrm{x}} \mathrm{Sr}_{1-\mathrm{x}} \mathrm{TiO}_{3}$ powders as shown in the second chemical reaction. Then BST powders were pressed in a suitable template at $(125 \mathrm{MPa})$ and sintered at $\left(1200^{\circ} \mathrm{C}\right)$ for $(8 \mathrm{hr})$ under vacuum.

$$
\begin{aligned}
& x \mathrm{BaCl}_{2}+(1-x) \mathrm{SrCl}_{2}+\mathrm{TiCl}_{4}+2(\mathrm{COOH})_{2}+5 \mathrm{H}_{2} \mathrm{O} \\
& \stackrel{{ }^{\circ} \mathrm{C} / 15 \mathrm{~min}}{\longrightarrow} \mathrm{Ba}_{\chi} \mathrm{Sr}_{1-\chi} \mathrm{Ti}_{2}\left(\mathrm{C}_{2} \mathrm{O}_{4}\right)_{2} \cdot 4 \mathrm{H}_{2} \mathrm{O}+6 \mathrm{HCl}+0.5 \mathrm{O}_{2} \\
& \mathrm{Ba}_{\chi} \mathrm{Sr}_{1-x} \mathrm{TiO}\left(\mathrm{C}_{2} \mathrm{O}_{4}\right)_{2} \cdot 4 \mathrm{H}_{2} \mathrm{O} \stackrel{850^{\circ} \mathrm{C} / 5 \mathrm{hr}}{\longrightarrow} \mathrm{Ba}_{\chi} \mathrm{Sr}_{1-x} \mathrm{TiO}_{3}+4 \mathrm{CO}+\mathrm{CO}_{2}+4 \mathrm{H}_{2} \mathrm{O}
\end{aligned}
$$

$\mathrm{X}$-ray diffraction analysis was done at room temperature using SHIMADZU diffractometer with CuK $\alpha 1$ and Ni filter $(\lambda=1.5406 \AA)$, the voltage $(40 \mathrm{kV})$ and current $(80 \mathrm{~mA})$ to estimate the crystal structure. The analysis was performed using XPowder software for calculations of lattice parameters. The crystallite size was applied by using Scherrer method for (111) peak and Williamson Hall method. The application of crystal impact match for phase identification addition to database of XRD represented by the following ASTM cards, (PDF2\# 81-2205 for BT, PDF2\# 44-0093 for BST77, PDF2\# 89-0274 for BST67, PDF2\# 34-0411 for BST6, PDF2\# 39-1395 for BST5 and PDF2\# 86-0179 for ST) concluded by International Center for Diffraction Data (ICDD). The cards number of crystallography open database, (COD\# 210-0858 for BT and COD\# 900-6864 for ST), concluded by International Union for Crystallography (IUCr) were used for specifications the produced powder. FTIR analyses were performed by KBr Disc, with reference code number (SDBS\# 40058) for BT from Japanese Spectral Database for Organic Compounds were used also.

\section{Result and Discussion}

XRD patterns of $\mathrm{Ba}_{\mathrm{x}} \mathrm{Sr}_{1-\mathrm{x}} \mathrm{TiO}_{3}$ are shown in Figure 2; the crystalline phases appeared after the calcination at $\left(850^{\circ} \mathrm{C} / 5 \mathrm{hrs}\right)$. It was clear that the BST-samples have crystal structure data is appeared in Table 2. There is a slightly deviation in lattice constants from cubic to tetragonal phase at $(x=0.8,0.9,1)$ as shown in Figure 3 . That was return to slightly shifting in the diffracted angles $(2 \theta)$ as investigated in Figure 2. That was happened due to the insertion of substituted atoms in the interstitial sites in the structure, the last one tend to partial change in the bonds length which are the elements of producing the Miller indices. Then the tetragonal phase was created for the samples (BT, BST9, and BST8) with non-centrosymmetric with space group: P4mm [15]. 


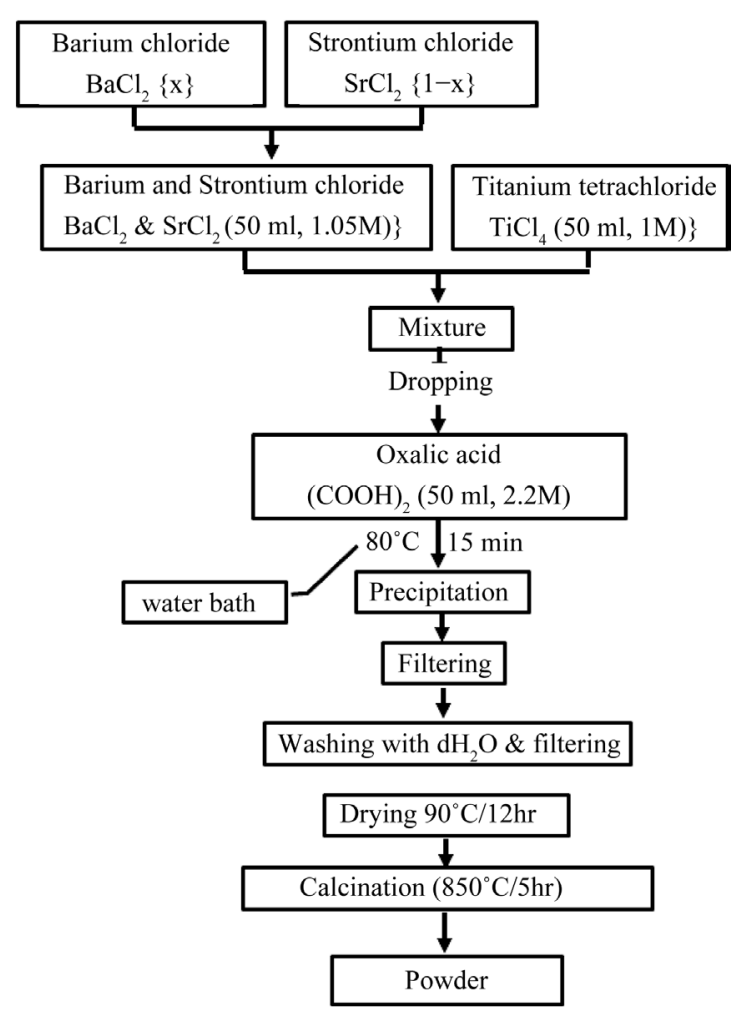

Figure 1. Schematic diagram for preparing $\mathrm{Ba}_{\mathrm{x}} \mathrm{Sr}_{1-\mathrm{x}} \mathrm{TiO}_{3}$ samples.

Table 1. Conditions and Molarity (M) of starting materials for preparing $\mathrm{Ba}_{\mathrm{x}} \mathrm{Sr}_{1-\mathrm{x}} \mathrm{TiO}_{3}$ powders.

\begin{tabular}{|c|c|c|c|c|c|c|c|}
\hline Sample & Formula & $\mathrm{BaCl}_{2}(\mathrm{M})$ & $\mathrm{SrCl}_{2}(\mathrm{M})$ & $\begin{array}{c}\mathrm{BaCl}_{2} \& \\
\mathrm{SrCl}_{2}(\mathrm{M})\end{array}$ & $\mathrm{TiCl}_{4}(\mathrm{M})$ & Oxalic acid (M) & Precursor \\
\hline $\mathrm{BT}$ & $\mathrm{BaTiO}_{3}$ & 1.05 & 0 & 1.05 & 1 & 2.2 & $\mathrm{BaTiO}(\mathrm{COO})_{2} \cdot 4 \mathrm{H}_{2} \mathrm{O}$ \\
\hline BST9 & $\mathrm{Ba}_{0.9} \mathrm{Sr}_{0.1} \mathrm{TiO}_{3}$ & 0.945 & 0.105 & 1.05 & 1 & 2.2 & $\mathrm{Ba}_{0.9} \mathrm{Sr}_{0.1} \mathrm{TiO}(\mathrm{COO})_{2} \cdot 4 \mathrm{H}_{2} \mathrm{O}$ \\
\hline BST8 & $\mathrm{Ba}_{0.8} \mathrm{Sr}_{0.2} \mathrm{TiO}_{3}$ & 0.84 & 0.21 & 1.05 & 1 & 2.2 & $\mathrm{Ba}_{0.8} \mathrm{Sr}_{0.2} \mathrm{TiO}(\mathrm{COO})_{2} \cdot 4 \mathrm{H}_{2} \mathrm{O}$ \\
\hline BST7 & $\mathrm{Ba}_{0.7} \mathrm{Sr}_{0.3} \mathrm{TiO}_{3}$ & 0.735 & 0.315 & 1.05 & 1 & 2.2 & $\mathrm{Ba}_{0.7} \mathrm{Sr}_{0.3} \mathrm{TiO}(\mathrm{COO})_{2} \cdot 4 \mathrm{H}_{2} \mathrm{O}$ \\
\hline BST6 & $\mathrm{Ba}_{0.6} \mathrm{Sr}_{0.4} \mathrm{TiO}_{3}$ & 0.63 & 0.42 & 1.05 & 1 & 2.2 & $\mathrm{Ba}_{0.6} \mathrm{Sr}_{0.4} \mathrm{TiO}(\mathrm{COO})_{2} \cdot 4 \mathrm{H}_{2} \mathrm{O}$ \\
\hline BST5 & $\mathrm{Ba}_{0.5} \mathrm{Sr}_{0.5} \mathrm{TiO}_{3}$ & 0.525 & 0.525 & 1.05 & 1 & 2.2 & $\mathrm{Ba}_{0.5} \mathrm{Sr}_{0.5} \mathrm{TiO}(\mathrm{COO})_{2} \cdot 4 \mathrm{H}_{2} \mathrm{O}$ \\
\hline ST & $\mathrm{SrTiO}_{3}$ & 0 & 1.05 & 1.05 & 1 & 2.2 & $\mathrm{SrTiO}(\mathrm{COO})_{2} \cdot 4 \mathrm{H}_{2} \mathrm{O}$ \\
\hline
\end{tabular}

That means there is no center for symmetry, and they have spontaneous polarization related to the crystal structure. The samples (BST7, BST6, BST5, and ST) have cubic phase and centrosymmetric with space group: Pm-3m [15]. That means there is a center of symmetry, and no spontaneous polarization was appeared in this phase. This phase transition tend to say that the samples (BT, BST9, BST8) has ferroelectric behavior with Curie temperature is greater than room temperature, while the samples (BST7, BST6, BST5, ST) has paraelectric with Curie temperature is lower than room temperature. On the other hand the lattice parameters change linearly with the substitution factor $(\mathrm{x})$ as shown in the following equations. The difference in the ionic radius between $\left(\mathrm{Ba}^{2+}=1.35 \AA\right)$ and $\left(\mathrm{Sr}^{2+}=1.13 \AA\right)$ play an important roles on the linear variation of lattice constants as a function of $(x)$.

$$
\begin{array}{ll}
c(\AA)=0.120 x+3.898 & \\
a(\AA)=0.120 x+3.898 & \text { for } 0.7>x>0 \\
a(\AA)=0.058 x+3.941 & \text { for } x \geq 0.7
\end{array}
$$




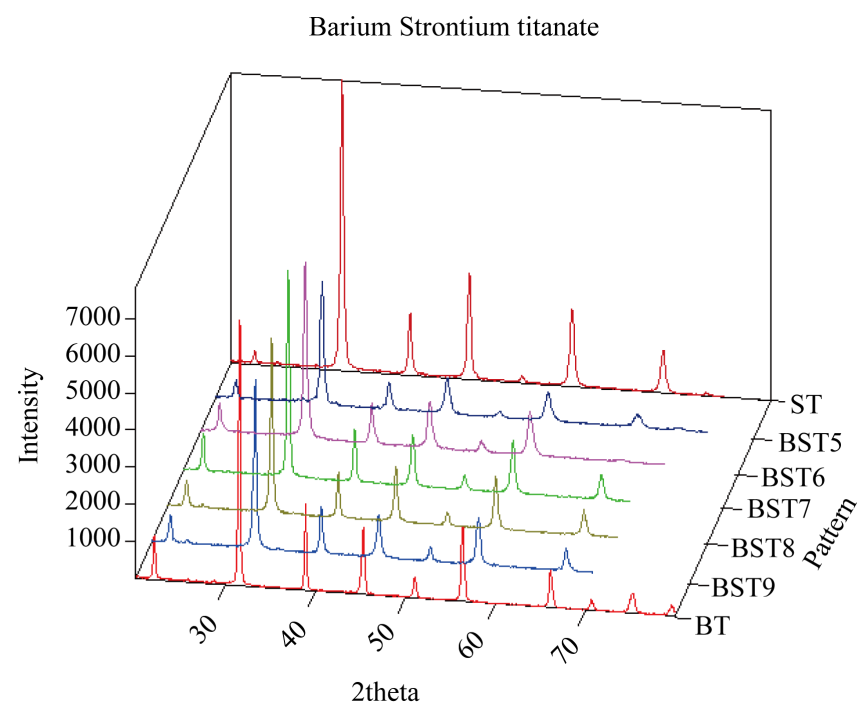

Figure 2. 3D XRD pattern for BST after calcination at $\left(850^{\circ} \mathrm{C} / 5 \mathrm{hrs}\right)$.

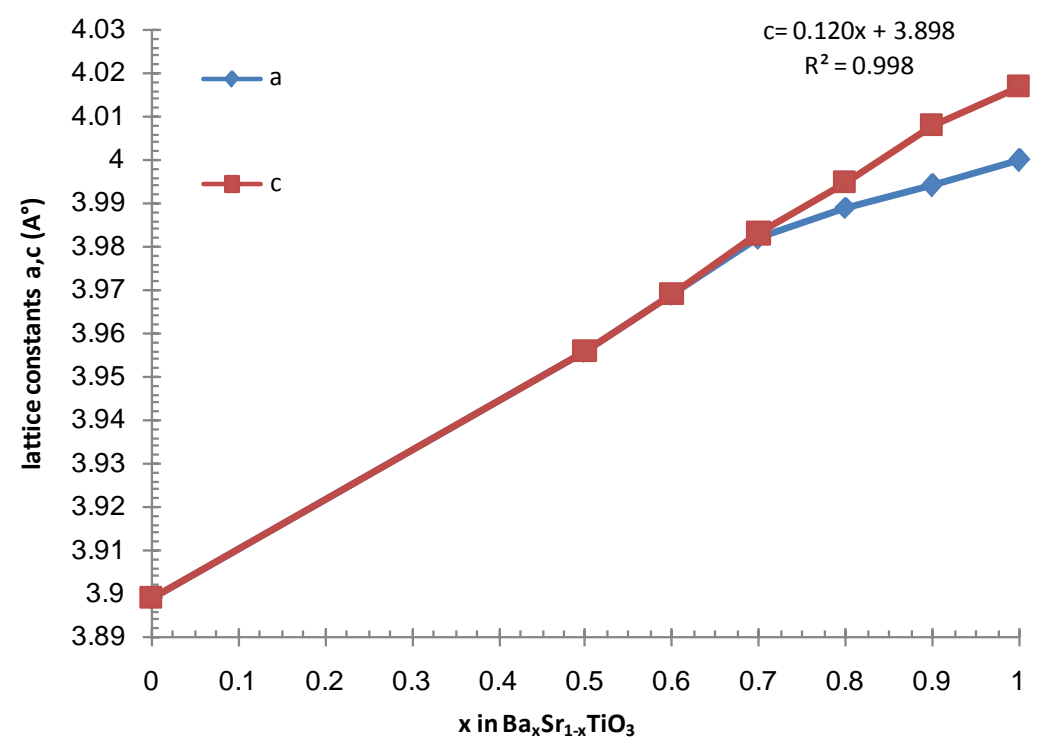

Figure 3. Variation of lattice parameter with substitution factor $(x)$ in $\mathrm{Ba}_{\mathrm{x}} \mathrm{Sr}_{1-\mathrm{x}} \mathrm{TiO}_{3}$.

Table 2. Phases, crystallite sizes and particle size of BST samples calcined at ( $\left.850^{\circ} \mathrm{C} / 5 \mathrm{hrs}\right)$.

\begin{tabular}{ccccccc}
\hline Sample & a $(\AA)$ & c $(\AA)$ & Lattice & Space group & $\begin{array}{c}\text { Crystallite size }(\mathrm{nm}) \\
\text { from XRD }\end{array}$ & $\begin{array}{c}\text { Particle size }(\mathrm{nm}) \\
\text { from TEM }\end{array}$ \\
\hline ST & 3.899 & 3.899 & Cubic & Pm-3m & $24-29$ & - \\
BST5 & 3.956 & 3.956 & Cubic & Pm-3m & $23-28$ & 70 \\
BST6 & 3.969 & 3.969 & Cubic & Pm-3m & $24-90$ & 95 \\
BST7 & 3.982 & 3.983 & Tetragonal & P4mm & $25-38$ & - \\
BST8 & 3.989 & 3.995 & Tetragonal & P4mm & $21-26$ & 40 \\
BST9 & 3.994 & 4.008 & Tetragonal & P4mm & $21-45$ & - \\
BT & 3.9999 & 4.017 & Tetragonal & P4mm & $29-89$ & - \\
\hline
\end{tabular}


The experimental results of this study in agreement with theoretical (lattice constant-concentration) phase diagram of phase transitions by the symmetry transition (P4mm-Pm-3m) [15].

FTIR spectra of different samples showed that the absorption peaks were at a wave vector $(555.5,540$ and $526.5 \mathrm{~cm}^{-1}$ ) related to ST, BST5, BT respectively as shown in Figure 4. Those peaks are related to perovskite structure due to their analysis with SDBS database \#40058 for BT and FDM database \#00334 for ST. there is a broad absorption band in previous study [16], which exhibited the change of absorption band was about (500 $\left.560 \mathrm{~cm}^{-1}\right)$ as a function of $(x)$. The change of wave vector with the factor $(x)$ showed that there is a linear behavior in the absorption that is clear in Figure 5. There is a simulated equation was concluded, it appeared the increasing of Sr-ions with respect to Ba-ions lead to slightly increasing in the wave vector in absorption lines. That means the increasing of Sr-ions, decreasing in $(x)$, lead to decrease the bond length and increasing of the bond energy, this result was agreed with XRD results. The presence of perovskite structure with different lattice parameter is agreed with FTIR results. It showed that there is increasing linearly with the wave vector as $(x)$ decreased. The following equation is a simulated equation explains the effect of $(x)$ on the variation of wave vector.

$$
K\left(\mathrm{~cm}^{-1}\right)=-29 x+555.1
$$

Transmission electron microscope (TEM) is a good tool to explain the nature of fine powder and exhibited

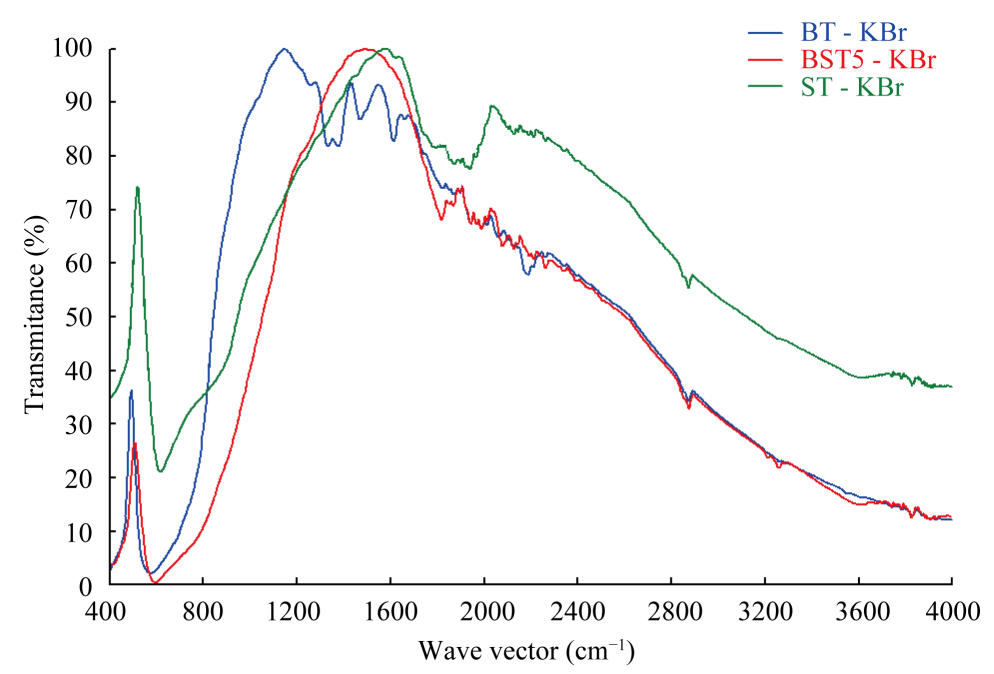

Figure 4. FTIR spectrum for BST samples.

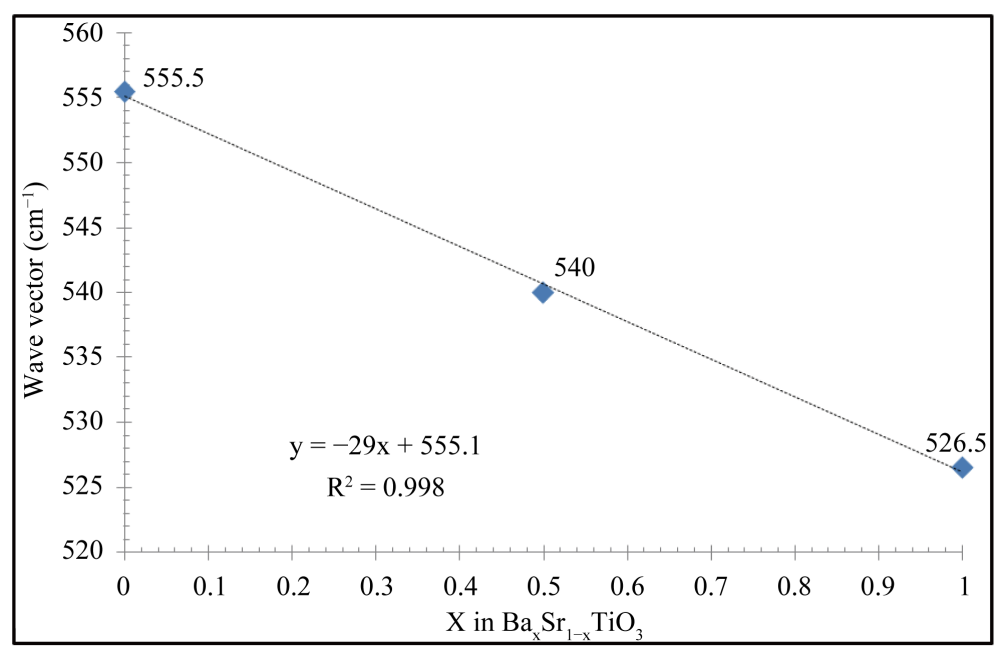

Figure 5. Variation of absorption in wave number with substitution factor $(x)$. 
nanoparticles. There are many images exhibited in many figures as a function of $(x)$. It was clear that the sample BST5 showed the particle size in the range (68 - $99 \mathrm{~nm}$ ) with agglomeration as shown in Figure 6. On the other hand, the selected area electron diffraction (SAED) pattern showed that the powder have polycrystalline structure in agreement with the XRD data analysis. The sample BST6 showed that the particle size in the range (77 $140 \mathrm{~nm}$ ) with agglomeration as appeared in Figure 7, Figure 8. The second thing, the SAED pattern as in Figure 7, it was showed that the powder had a polycrystalline structure. Whereas the SAED pattern in Figure 8, it was belong to particle surrounded be the yellow circle, so this pattern may be either superstructure or single crystal and this result is in a contradiction with the result of XRD obtained. Finally, the sample BST8 was showed the particle size in the range $(36$ - $50 \mathrm{~nm}$ ) with low agglomeration as shown in Figure 9, and the SAED analysis give us the polycrystalline phase for the produced powder in agreement with XRD analysis that was agreement with the previous study [17].

\section{Conclusion}

The system $\left(\mathrm{Ba}_{\mathrm{x}} \mathrm{Sr}_{1-\mathrm{x}} \mathrm{TiO}_{3}\right)$ is a solid solution between $\mathrm{BaTiO}_{3}$ and $\mathrm{SrTiO}_{3}$ as mentioned elsewhere, so BST have adjustable physical properties by varying the substitution factor $(x)$. There is a phase transition from cubic to tetragonal phase at $(x>0.7)$. On the other hand, there is an agreement between FTIR and XRD results about the perovskite structure. In general, the procedure of oxalate co-precipitation method showed that it is efficient and

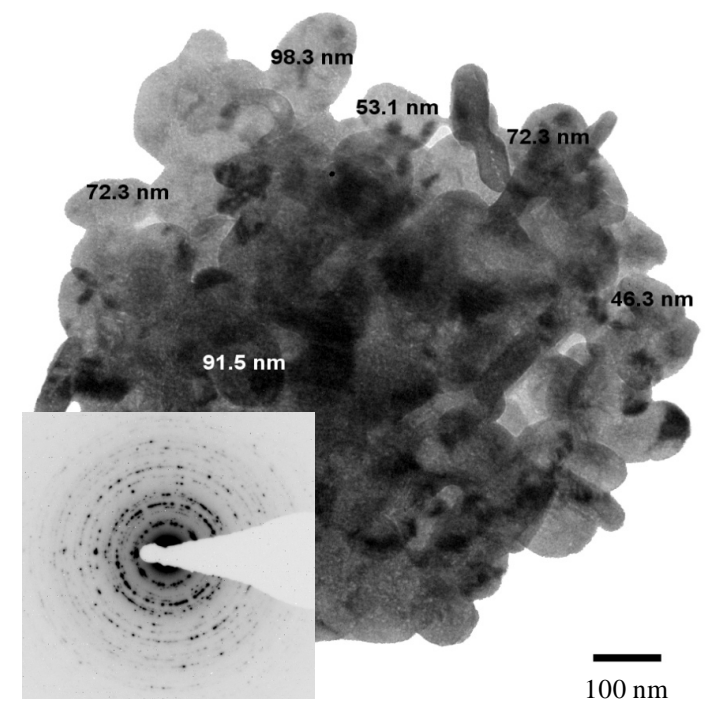

Figure 6. TEM image and SAED for BST5.

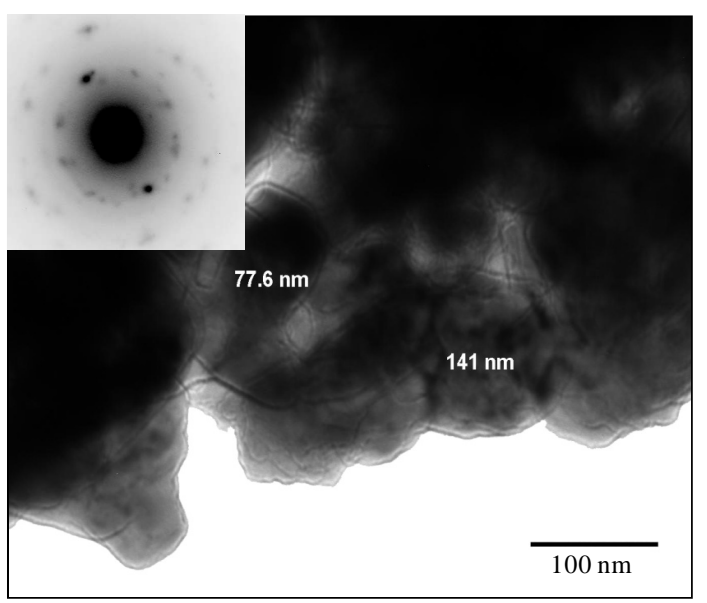

Figure 7. TEM image and SAED for BST6. 


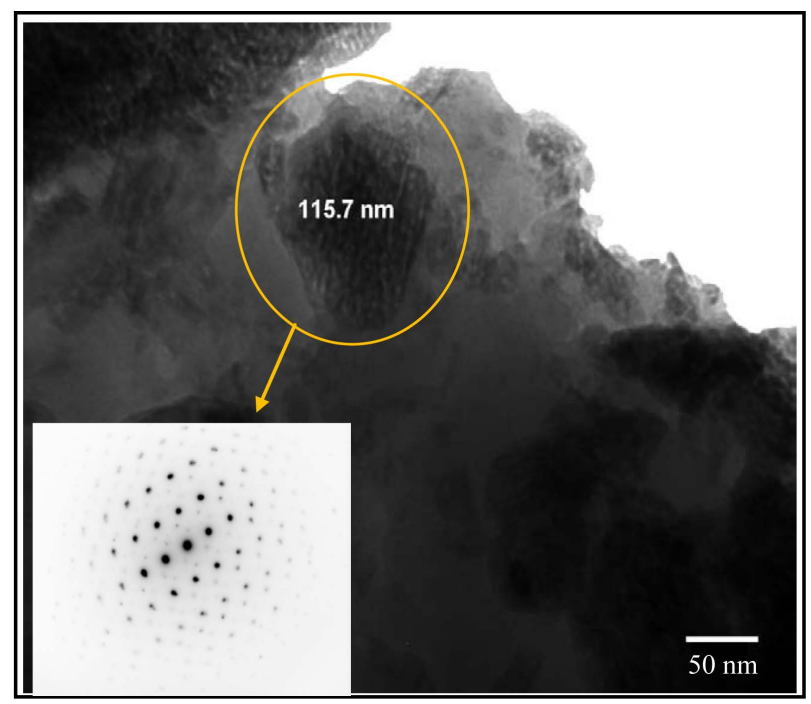

Figure 8. TEM image and SAED for BST6.

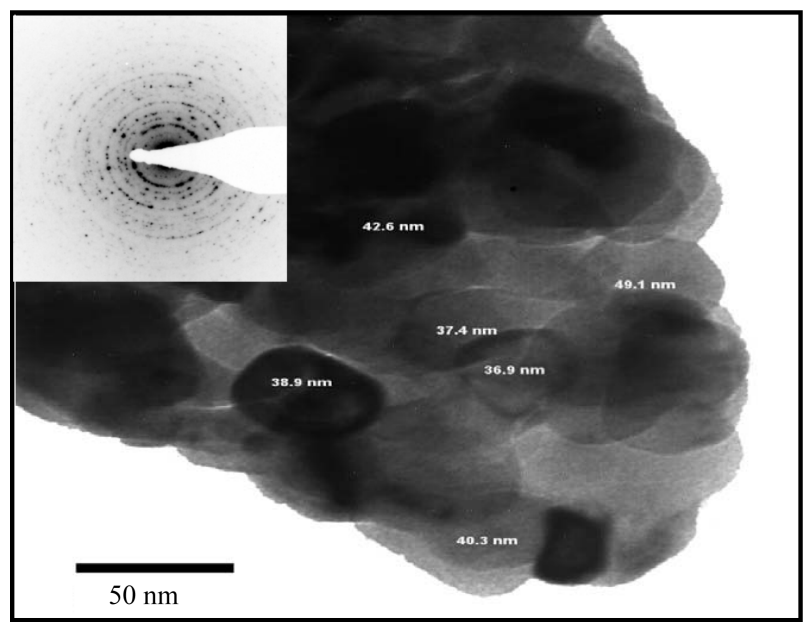

Figure 9. TEM image and SAED for BST8.

quickly method to produce fine powder with particle size in the range of nanosize. The obtainable best particle size was in the range (36 - $50 \mathrm{~nm}$ ). We conclude many simulated equations made collaboration between the concentration of $(x)$ with the lattice constants and the wave vector. Both last parameters showed that there is a dependence on each other.

\section{Acknowledgements}

We are very grateful to Ministry of High Education in Iraq for encourage us through providing the scholarship to complete the requirement of this research at La Rochelle University/France. Many thank directed to Prof. Brahim Elouadiat La Rochelle University/France for his collaboration and advising in the analysis and measurements those were done. It is necessary to thank Prof. Xavier Feaugas at La Rochelle University/France for his helpful in the analysis of TEM photos.

\section{References}

[1] Kao, K. (2004) Dielectric Phenomena in Solids. Elsevier Academic Press, San Diego.

[2] Mantese, J. and Alpay, S. (2005) Graded Ferroelectrics, Transpacitors and Transponent. Ch. 2, Springer, USA.

[3] Muller, K.A. and Kool, T.W., Eds. (2010) Properties of Perovskites and Other Oxides. World Scientific Publishing Co. 
Pte. Ltd., USA.

[4] Hung, K.M., Yang, W.D. and Huang, C. (2003) Journal of the European Ceramic Society, 23, 1901-1910. http://dx.doi.org/10.1016/S0955-2219(02)00431-4

[5] Sharma, P.K., Varadan, V.V. and Varadan V.K. (2003) Journal of the European Ceramic Society, 23, 659-666. http://dx.doi.org/10.1016/S0955-2219(02)00191-7

[6] Razak, K.A., Asadov, A., Yoo, J., Haemmerle, E. and Gao, W. (2008) Journal of Alloys and Compounds, 449, 19-23. http://dx.doi.org/10.1016/j.jallcom.2006.02.093

[7] Brankovic, G., Brankovic, Z., Goes, M.S., Paiva, C.O., Cilense, M., Varela, J.A. and Longo, E. (2005) Materials Science and Engineering: B, 122, 140-144. http://dx.doi.org/10.1016/j.mseb.2005.05.016

[8] Hwu, J., Yu, W., Yang, W., Chen, Y. and Chou, Y. (2005) Materials Research Bulletin, 40, 1662-1679. http://dx.doi.org/10.1016/j.materresbull.2005.05.019

[9] Kim, S., Lee, M., Noh, T. and Lee, C. (1996) Journal of Materials Science, 31, 3643-3645. http://dx.doi.org/10.1007/BF00352772

[10] Mahmood, N.B. and Al-Shakarchi, E.K. (2011) Journal of Modern Physics, 2, 1420-1428. http://dx.doi.org/10.4236/jmp.2011.211175

[11] Khollam, Y.B., Deshpande, S.B., Potdar, H.S., Bhoraskar, S.V., Sainkar, S.R. and Date, S.K. (2005) Materials Characterization, 54, 63-74. http://dx.doi.org/10.1016/j.matchar.2004.11.002

[12] Jhung, S., Lee, J., Yoon, J., Hwang, Y., Hwang, Y., Park, S. and Chang, J. (2004) Materials Letters, 58, $3161-3165$. http://dx.doi.org/10.1016/j.matlet.2004.06.006

[13] Simon-Seveyrat, L., Hajjaji, A., Emziane, Y., Guiffard, B. and Guyomar, D. (2007) Ceramics International, 3, 35-40. http://dx.doi.org/10.1016/j.ceramint.2005.07.019

[14] Khollam, Y., Bhoraskar, S., Deshpande, S., Potdar, H., Pavaskar, N., Sainkar, S. and Date, S. (2003) Materials Letters, 57, 1871-1879. http://dx.doi.org/10.1016/S0167-577X(02)01091-1

[15] Hahn, T. (2005) International Tables for Crystallography. Volume A: Space-Group Symmetry. Springer, New York.

[16] Kao, C.F. and Yang, W.D. (1999) Applied Organometallic Chemistry, 13, 383-397. http://dx.doi.org/10.1002/(SICI)1099-0739(199905)13:5<383::AID-AOC836>3.0.CO;2-P

[17] Verma, K., Sharma, S., Sharma, D.K., Kumar, R. and Rai, R. (2012) Advanced Materials Letters, 3, 44-49. http://dx.doi.org/10.5185/amlett.2011.5264 
Scientific Research Publishing (SCIRP) is one of the largest Open Access journal publishers. It is currently publishing more than 200 open access, online, peer-reviewed journals covering a wide range of academic disciplines. SCIRP serves the worldwide academic communities and contributes to the progress and application of science with its publication.

Other selected journals from SCIRP are listed as below. Submit your manuscript to us via either submit@scirp.org or Online Submission Portal.
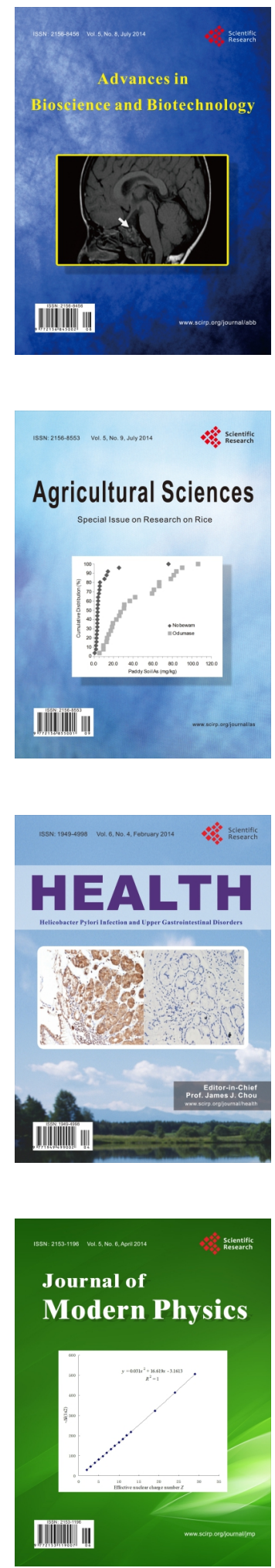
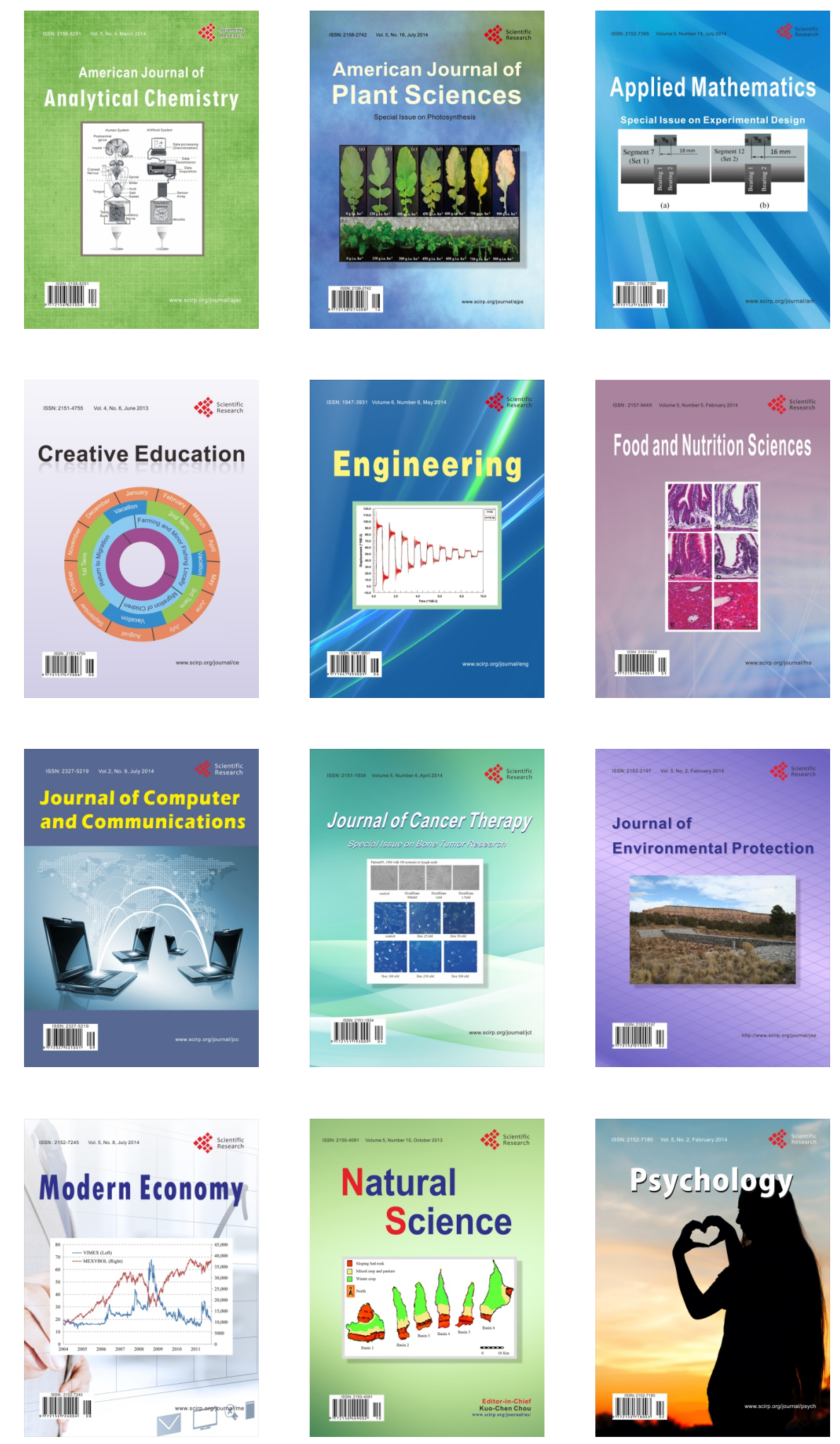